\title{
Outcome of Second Line Chemotherapy (Gemcitabine, Dexamethasone, and Cisplatin) in Relapsed and Refractory Non Hodgkin Lymphoma
}

\author{
YOUSRYEIA A. AHMAD, M.D.*; RANIA HAFEZ, M.D.*; SABRIN REFAAT, M.Sc.* and \\ MARWA ISMAIL, M.D.** \\ The Department of Internal Medicine, Clinical Hematology Unit* and The Department of Clinical Oncology**, \\ Faculty of Medicine, Assiut University, Assiut, Egypt
}

\begin{abstract}
Background: The treatment of patients with relapsed or refractory non-Hodgkin lymphoma remains challenging. The strategy for management of relapsed or refractory disease is to deliver salvage chemotherapy, followed by autologous stem-cell transplantation in responding patient. Such salvage therapies typically consist of cytotoxic agents that have not been used in first line therapy.
\end{abstract}

Aim of Study: In this study we are trying to study one of the salvage chemotherapy lines which is GDP regarding response rate, quality of life and toxicity.

Patients and Methods: Seventy patients diagnosed as refractory or relapsed NHL were included in the study; all patients received GDP for 4 to 6 cycles. Primary end point was to evaluate overall response to treatment; secondary end point was to evaluate quality of life and toxicity. An informed written consent was obtained from all the patients and approval of Research Ethics Committee of Assiut, Faculty of Medicine was obtained prior to the study.

Results: The overall response was $65 \%$ with complete response $25 \%$ and partial response $40 \%$. Regarding quality of life it was noticed that $32.9 \%$ patients using GDP were improved, $40 \%$ were stable patients while significant deterioration occurred in $27.1 \%$. Regarding toxicity profile, occurrence of neutropenia was $50 \%$ with grade III-IV $15 \%$, thrombocytopenia $40 \%$ with grade IV-V 5\%, anemia $60 \%$ with grade II-III $7 \%$. Nausea $50 \%$ with grade III-IV 3\%, vomiting $40 \%$ with grade III-IV $10 \%$, diarrhea $34.3 \%$ with grade II-III $5 \%$. Renal toxicity $31.4 \%$ with grade I-II $15 \%$, neurological toxicity $40 \%$ grade I-II $10 \%$. Hepatic toxicity $25.7 \%$ with grade I-II $20 \%$.

Conclusion: GDP is effective as second line chemotherapy with good response rate, quality of life and a manageable range of toxicity.

Key Words: GDP - NHL - Relapsed - Refractory lymphoma.

Declaration: No conflict of interest.

Correspondence to: Dr. Rania Hafez, E-Mail: raniahafez@ymail.com

\section{Introduction}

NON-HODGKIN Lymphomas (NHLs) are a heterogeneous group of neoplasm of the lymphatic system [1] that results from an uncontrollable proliferation of B or T lymphoid cells and Natural Killer (NK) cells [2]

Histologic type and stage are the main factors that treatment depends on in patients with NHL [3], in patients with invasive NHL; there are still reports of $50-60 \%$ of experience drug recurrence after the first-line treatment.

Patients are categorized depending on response to frontline chemotherapy as having primary refractory disease (failure to have a Complete Response (CR), progression or transient response upon frontline therapy, CR/Partial Response (PR) lasting ${ }^{<3}$ months), early relapse (CR lasting $<12$ months) and late relapse (CR lasting $>12$ months) [4].

The treatment strategy for relapsed or refractory lymphoma is to deliver salvage chemotherapy, followed by autologous stem-cell transplantation in responsive patients [5].

The choice of salvage therapy is still debated; several second-line chemotherapy regimens-which are designed to increase the number of patients eligible for transplantation through the use of more intense chemotherapy-have been evaluated and were discovered to have considerable hematologic toxicity and use of health care resources [6].

Those salvage chemotherapies consist of cytotoxic drugs that have not been used in first line therapy. 
Gemcitabine is a cytidine analog that has the advantages of more rapid uptake by cells, more efficient phosphorylation, wide spectrum of antitumor activity and slower elimination [7].

In our study we tried to study one of the second lines of chemotherapy which is Gemcitabine, Dexamethasone, and Cisplatin (GDP) regarding response rate, toxicity and quality of life.

\section{Patients and Methods}

This prospective study was conducted at Clinical Hematology Unit in Internal Medicine Department and Medical Oncology Department, Assiut University Hospitals during 2015-2016, the study included 70 patients diagnosed as refractory or relapsed NHL, and the patients received Gemcitabine, Dexamethasone and Cisplatin (GDP) for 4 to 6 cycles.

\section{Those patients received GDP:}

- Gemcitabine $1,000 \mathrm{mg} / \mathrm{m}^{2}$ i.v. on days 1 and 8 .

- Dexamethasone 40mg i.v. on days 1-4.

- Cisplatin $75 \mathrm{mg} / \mathrm{m}^{2}$ i.v. on day 1 , every 21 days for 4 to 6 cycles.

All studied patients were subjected to full history taking, complete physical examination, laboratory investigations including complete blood count with differential count, liver function test, kidney function test and lactate dehydrogenase level, excisional lymph node biopsy with immunophenotyping to diagnose $\mathrm{B}$ or $\mathrm{T}$ cell type, multislice CT chest and abdomen for disease assessment, bone marrow aspirate and biopsy, international prognostic index calculation.

Re-evaluation of the patients regarding response according to Lugano response criteria for NHL after second, fourth and six cycles. Toxicity was evaluated after second, fourth and six cycles according to the Common Toxicity Criteria of the National Cancer Institute [8]

Quality of Life (QoL) assessment was done using the Functional Assessment of Cancer Therapy (FACT) instrument [9] which considers a change of $10 \%$ or more compared to baseline quality of life a meaningful change and classified into improved, stable and worse.

\section{Statistical analysis:}

The results of the study were tabulated and statistical analysis was carried out using statistical package for Social Science SPSS Version 20, using significant level $(p<0.05)$. Chi square test was used to compare frequencies.

\section{Results}

The study included 70 patients, 42 males $(60 \%)$ and 28 females (40\%) with age ranged from 28 to 54 years, 43 patients $(61.4 \%)$ were diagnosed as $\mathrm{B}$ cell lymphoma and 27 patients $(38.6 \%)$ as $\mathrm{T}$ cell lymphoma, constitutional symptoms were present in 47 patients $(67.1 \%)$ and were absent in 23 patients (32.9\%), according to response to previous treatment, 22 patients were refractory; 35 patients with relapse $<1$ year and 13 patients with relapse $>1$ year. IPI risk factor at study entry was low and low-intermediate risk was detected in 44 patients $(62.9 \%)$, high-intermediate risk was detected in 20 patients $(28.6 \%)$ and high risk was detected in 6 patients $(8.6 \%)$ (Table 1$)$.

Table (1): Characteristics of patients included in the study.

\begin{tabular}{ll}
\hline Variables & Number \\
\hline Age (years): & $51(28-54)$ \\
Median (range) & \\
Sex: & $42(60 \%)$ \\
Male & $28(40 \%)$ \\
Female & \\
Constitutional symptoms: & $47(67.1 \%)$ \\
Present & $23(32.9 \%)$ \\
Absent & \\
IPI risk factors at the entry: & $44(62.9 \%)$ \\
Low, low-intermediate risk & $20(28.6 \%)$ \\
High-intermediate risk & $6(8.6 \%)$ \\
High risk & \\
Histological type: & $43(61.4 \%)$ \\
B-cell & $27(38.6 \%)$ \\
T-cell & \\
Response to previous therapy: & $22(31.4 \%)$ \\
Refractory & $35(50 \%)$ \\
Relapse ${ }^{1}$ year & $13(18.6 \%)$ \\
Relapse >1 year & \\
&
\end{tabular}

It was noticed that age, sex, presence of constitutional symptoms, response to previous therapy and histological type had no effect on response or toxicity.

Regarding the International Prognostic Index; $6(8.6 \%)$ patients were high risk while majority of patients $(62.9 \%)$ were low and low-intermediate.

Over all response was observed in 46 patients $(65 \%)$. Complete response was observed in 18 patients $(25 \%)$ patients, partial response was observed in 28 patients $(40 \%)$ (Table 2$)$. 
Table (2): Overall response rate.

\begin{tabular}{ll}
\hline & $(\mathrm{n}=70)$ \\
\hline Intention to treat population: & $70 / 70$ \\
Overall response rate & $46(65 \%)$ \\
Partial response & $28(40 \%)$ \\
Complete response & $18(25 \%)$ \\
\hline
\end{tabular}

Characteristics of patients who enter into complete response were; age group between 29 and 45 years, B symptoms were positive, IPI index was low and low-intermediate, previous treatment was RTH and Anthracycline, early relapse was 20\% and late relapse was $50 \%$ (Table 3 ).

Characteristics of patients who enter into partial response were; age group between 30 and 60 years, B symptoms were positive, IPI index was lowintermediate, high-intermediate and high risk, previous treatment was RTH and Anthracycline, early relapse was $40 \%$ and late relapse was $25 \%$ (Table 3).

Table (3): Details of patients who enter in complete and partial response.

\begin{tabular}{lcccccc}
\hline & \multicolumn{2}{c}{ Age B symptoms } & \multicolumn{1}{c}{ IPI index } & Previous TT & Early relapse & Late relapse \\
\hline Complete response & $29-45$ & + ve & Low, low-intermediate & RTH Anthracycline & $20 \%$ & $50 \%$ \\
Partial response & $30-60$ & + ve & $\begin{array}{l}\text { High-intermediate } \\
\text { Low-intermediate \& } \\
\text { high risk }\end{array}$ & RTH Anthracycline & $40 \%$ & $25 \%$ \\
\hline
\end{tabular}

According to the type of lymphoma overall response was observed in $34(80 \%)$ and $18(68 \%)$ patients in B-cell and T-cell subtypes respectively (Table 4).

Table (4): Overall response based on types of lymphoma.

\begin{tabular}{ccc}
\hline & B-cell $(\mathrm{n}=43)$ & T-cell $(\mathrm{n}=27)$ \\
\hline Overall response & $34(80)$ & $18(68)$ \\
\hline
\end{tabular}

Those patients who relapsed after previous therapy had higher frequency of response to the second line than those who were refractory to previous therapy $40(83.33 \%)$ vs. $13(57.1 \%)$ patients (Table 5).

Table (5): Overall response based on response to previous therapy.

\begin{tabular}{lcc}
\hline & Relapse $(\mathrm{n}=48)$ & Refractory $(\mathrm{n}=22)$ \\
\hline Overall response & $40(83.33)$ & $13(57.1)$ \\
\hline
\end{tabular}

The event of interest was death of the patients during the duration of the study whether improved or not and other cases were considered censored (Table 6).

Table (6): Summary of cases according to survival analysis.

\begin{tabular}{ccc}
\hline & Number of event & Number of censored \\
\hline GDP regimen & $9(12.86)$ & $61(87.14)$ \\
\hline
\end{tabular}

It was noticed that occurrence of neutropenia, nausea, vomiting, diarrhea, and hepatic toxicity are the main side effects, neutropenia $50 \%$ with grade III-IV $15 \%$, thrombocytopenia $40 \%$ with grade IV-V 5\%, anemia $60 \%$ with grade II-III $7 \%$. Nausea $50 \%$ with grade III-IV $3 \%$, vomiting $40 \%$ with grade III-IV $10 \%$, diarrhea $34.3 \%$ with grade II-III $5 \%$. Renal toxicity $31.4 \%$ with grade I-II $15 \%$, neurological toxicity $40 \%$ grade I-II $10 \%$. Hepatic toxicity $25.7 \%$ with grade I-II $20 \%$ (Table 7).

Table (7): Adverse effects of both regimens.

\begin{tabular}{ll}
\hline Variables & $(\mathrm{n}=70)$ \\
\hline Hematological adverse effects: & \\
Anemia & $30(60 \%)$ \\
Grade II-III & $7 \%$ \\
Neutropenia & $35(50 \%)$ \\
Grade III-IV & $15 \%$ \\
Thrombocytopenia & $28(40 \%)$ \\
Grade IV-V & $5 \%$ \\
Gastrointestinal effects: & \\
Nausea & $35(50 \%)$ \\
Grade III-IV & $3 \%$ \\
Vomiting & $28(40 \%)$ \\
Grade III-IV & $10 \%$ \\
Diarrhea & $24(34.3 \%)$ \\
Grade II-III & $5 \%$ \\
Renal toxicity: & $22(31.4 \%)$ \\
Grade I-II & $15 \%$ \\
Neurological toxicity: & $28(40 \%)$ \\
Grade I-II & $10 \%$ \\
Hepatic toxicity: & $18(25.7 \%)$ \\
Grade I-II & $20 \%$ \\
\hline
\end{tabular}

It was noticed that 23 patients $(32.9 \%)$ were improved, stable patients were $28(40 \%)$ while significant deterioration occurred in 19 patients (27.1\%) (Table 8). 
Table (8): Quality of life assessment.

\begin{tabular}{ll}
\hline & $(\mathrm{n}=70)$ \\
\hline QoL assessment: & \\
Improved & $23(32.9)$ \\
Stable & $28(40)$ \\
Worse & $19(27.1)$ \\
\hline
\end{tabular}

No follow-up was done for the patients after entery into the response was detected as this was the end point of the study.

\section{Discussion}

Refractory non-Hodgkin lymphoma is that lymphoma that hasn't responded to initial treatment, progressive or has a transient response to treatment, relapsed non-Hodgkin lymphoma is NHL that responded to treatment but then returns, relapse may occur several months to years after the initial remission.

Patients with aggressive lymphoma, refractory or relapsed after frontline chemotherapy experience superior overall survival when treated with highdose chemotherapy with stem-cell transplantation for chemo sensitive patients [10].

In this study we tried to study one of the salvage chemotherapy lines which is GDP regarding response rate, quality of life and toxicity.

The current study included 70 patients received GDP regimen. Regarding response rate, in the current study over all response were observed in 46 patients $(65 \%)$, complete response was $25 \%$ and partial response was $40 \%$, those results were similar to a study by Ismaeil, et al., [11] which include sixty two patients with histological diagnosis of relapsed or refractory DLBCL 43 males and 19 females, with a median age 48 years (range 19-63) received GDP or DHAP-it was reported that overall response rate was $65 \%, 29 \%$ complete response and 38\% partial response in GDP group, those similar response rates may be due to similar patient inclusion criteria.

In another study by Fei Qi, et al., [13]-in which twenty-five patients were reviewed with relapsed or refractory PTCL-NOS, median age was 50 years (range 14-72 years), all patients received GDP regimen as second-or third-line chemotherapyrevealed that overall response was observed in 16 patients (64.0\%), complete response was observed in 4 patients $(16 \%)$ and partial response was 11 patients (44\%).

Also another study by Ghio, et al., [10]-from February 2006 to July 2014, 45 relapsed/refractory
DLBCLs patients treated with GDP-R, eligibility criteria were men or women aged $>18$ yearsreported that overall response rate was $48.8 \%$, complete response $15 / 45$ (33.3\%) and partial response $7 / 45$ (15.5\%), those different response rates may be due to higher percentage of high risk patients on the study.

There was significant difference in the overall response according to response to the previous therapy where those patients who were relapsed after previous therapy had higher frequency of response to the second line than those who were refractory to previous therapy $30(83.33 \%)$ vs. 48 $(57.1 \%)$ patients.

In a study by Ismaeil, et al., [11] it reported that better response was observed in patients who had complete response after the previous chemotherapy.

Regarding toxicity, in the current study it was noticed that occurrence of neutropenia was 35 $(50 \%)$, this finding also in agreement with Ismaeil, et al., [11] that reported that neutropenia was $62.9 \%$ in patients.

And in contrast with another study by Crump M, et al., [12]-which include 619 patients with relapsed/refractory aggressive lymphoma randomly assigned to treatment with GDP or DHAP-by it was noticed that Grade 3 or 4 adverse events were observed significantly less frequently during the first two cycles of chemotherapy among patients receiving GDP (47\%).

In the current study it was noticed that occurrence of hepatic toxicity was $18(25.7 \%)$, this finding was in agreement with a study by Fei Qi, et al., [13] which noticed that seven patients $(26.0 \%)$ had liver dysfunction indicated by moderately elevated alanine aminotransferase and aspartate aminotransferase in serum.

In the current study it was reported that occurrence of other adverse effects as renal was $31.4 \%$ and neurological was $40 \%$, those finding were in contrast to a study by Ismaeil, et al., [11] that reported that renal toxicity occur in $76 \%$ and neurological toxicity in $60 \%$.

In the current study it was reported occurrence of thrombocytopenia was $40 \%$, this finding was in agreement with a study by Crump M., et al., [12] reported that patients allocated to GDP required fewer platelet transfusions (31\%).

QoL assessment using Functional Assessment of Cancer Therapy (FACT-Total) scores showed that $23(32.9 \%)$ patients using GDP were improved, 
stable patients were $28(40 \%)$ while more significant deterioration was occurred in19 $(27.1 \%)$ patients, this finding was in agreement with Crump, et al., [12] that showed that, compared with baseline status, there was less deterioration among patients who were allocated to GDP, also more patients receiving GDP had an improved clinically meaningful change score $(18 \%)$ in patients received GDP and fewer had a worse clinically meaningful change score (33\%), also fewer patients receiving GDP required hospitalization (47\%).

\section{Recommendation:}

Our study recommends that is for patients who are in need to receive GDP to be early age group, with less co morbidities so they can overcome the toxicities that result from receiving the treatment.

\section{References}

1- ROGERS B.B.: Overview of non-Hodgkin's Lymphoma. Semin. Oncol. Nurs., 2: 67-72, Arch. Pathol. Lab. Med., 130: 1712-4, 2006.

2- WOOD N.H., FELLER L. and RAUBENHEIMER E.J.: Human immunodeficiency virus (HIV)-associated extra nodal $\mathrm{T}$ cell non-Hodgkin lymphoma of the oral cavity S.A.D.J., 63 (3): 158-61, 2008.

3- HOSTER E., BUSKE C. and DREYLING M.: The Follicular Lymphoma International Prognostic Index (FLIPI) separates high-risk from intermediate-or low-risk patients with advanced-stage follicular lymphoma treated frontline with rituximab and the combination of cyclophosphamide, doxorubicin, vincristine, and prednisone with respect to treatment outcome. Blood, 108: 1504-8, 2006.

4- MAURIZIO MUSSO, GIUSEPPE MESSINA and NICOLA Di RENZO: Improved outcome of patients with relapsed/refractory Hodgkin lymphoma with a new fotemustine-based high-dose chemotherapy regimen, 172 (1): 111-21, 2015

5- SCHMITZ N., PFI STNER B. and SEXTRO M.: Aggressive conventional chemotherapy compared with high- dose chemotherapy with autologous haemopoietic stemcell transplantation for relapsed chemosensitive Hodgkin's disease: A randomised trial. Lancet, 359: 2065-71, 2002.

6- JOSTING A., SIENIAWSKI M. and STAAK O.: Highdose sequential chemotherapy followed by autologous stemcell transplantation in relapsed and refractory aggressivenon-Hodgkin's lymphoma: Results of a multicenterphase II study. Annals of Oncology, 16: 1359-65, 2005.

7- JUSTYNA RYBKA, AGNIESZKA GIZA and WOJCIECH JURCZAK: Gemcitabine-Based Treatment in PoorPrognosis Patients with Relapsed and Refractory Hodgkin Lymphoma and Non-Hodgkin Lymphoma-a Multicenter Polish Experience Advances in Clinical and Experimental Medicine, 24 (5): 783-9, 2015.

8- TROTTI A., et al.: CTCAE v3. 0: Development of a comprehensive grading system for the adverse effects of cancer treatment. In Seminars in radiation oncology, 2003.

9- BURCKHARDT C.S. and K.L. ANDERSON: The Quality of Life Scale (QOLS): Reliability, validity, and utilization. Health Qual Life Outcomes, 1: p. 60, 2003.

10- GHIO F., CERVETTI G. and CECCONI N.: Prognostic factors and efficacy of GDP-R therapy in refractory/relapsed diffuse large B-cell lymphomas not eligible for high-dose therapy. J. Cancer Metastasis. Treat., 2: $5963,2016$.

11-ISMAEIL S., HUSSEIN K. and YASSIN M.: Gemcitabine, Dexamethasone, and Cisplatin (GDP) versus Dexamethasone, Cytarabine, and Cisplatin (DHAP) as Salvage Chemotherapy for Patients With Relapsed or Refractory Diffuse Large B-cell Lymphoma (DLBCL). J. Clin. Oncol. Nucl. Med., Vol. 9, No. 3-4: 91-7, 2013.

12- CRUMP M., SESHADRI T. and KURUVILLA J.: Salvage Therapy for Relapsed/Refractory Diffuse Large B Cell Lymphoma. Official journal of the American Society of Clinical Oncology. March Volume 14, Issue 3, Pages 25967, 2013.

13- FEI QI, MEI DONG and XIAOHUI HE: Gemcitabine, dexamethasone, and cisplatin (GDP) as salvage chemotherapy for patients with relapsed or refractory peripheral T cell lymphoma-not otherwise specified Ann. Hematol., 96: 245-51, 2017. 


\section{نتائج الخط العلاجى الكيميائى الثانى (جيمسيتابين، ديكساميثازون وسيسبلاتئين)

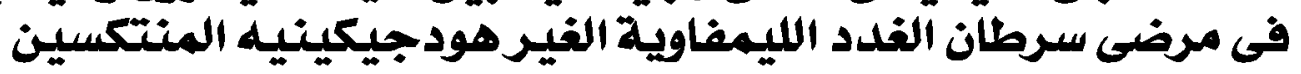

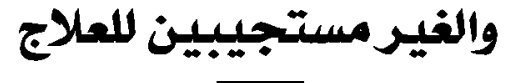

سرطان الغدل الليمفاوية الغير هولجيكينيه هو مجموعة غير متجانسة من الآورام فى الجهاز اللمفاوى والتى تنتج عن إنتشار لا يمكن السيطرة عليها من الخلايا الليمفاوية البائية آو التائيه والخلايا القاتية الطبيعية.

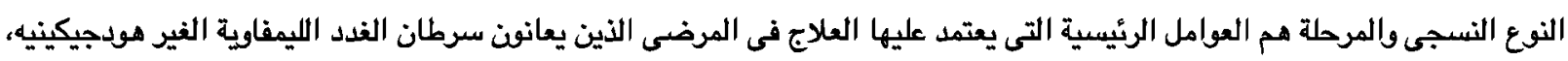

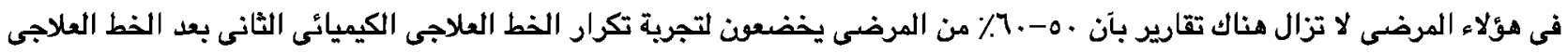

إستراتيجية العلاج فى مرضى سرطان الفدد اللمفاوية الفير هودجيكينيه المنتكسين والغير مستجيبين اللعلاج هو تقديم علاج كيميائى

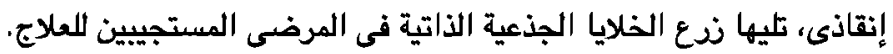
وتتكن هذه العلاجات الكيميائية من العلاجات التى لم تستخدم فى الخط الكيميائى الآول. ويتميز جيمسيتابين بآن له إمتصاص آكثر سرعة من قبل الخلايا وبطء فى التخلص منه، آكثر فعالية الفسفرة ومجموعة واسعة من النشاط. في دراستنا هذه حاولنا دراسة واحدة من الخطوط الثانية من العلاج الكيميائى الذى هو جيمسيتابين، ديكساميثازنو، وسيسبلاتين فيما يتعلق معدل الإستجابة، السمية وكفاءة الحياة.

الهدف من الدراسة: النقطة النهاية الآولية هى تقييم الإستجابة الشاملة للعلاج والنقطة النهاية الثانوية هى تقييم كفاءة الحياة بعد تلقى العلاج والسمية الناتجة عنه.

نتيجة الدراسة: آجريت هذه الدراسة الإستطلاعية في وحدة آمراض الدم السريرية في قسم الطب الباطنى وقسم الآودام الطبى فى الطي

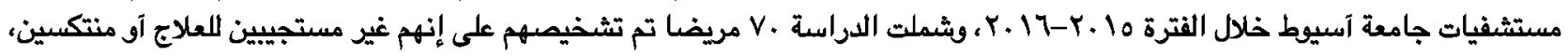
وتلقى المرضى جيمسيتابين، ديكساميثانهن وسيسبلاتين لمدة ع إلى 7 دورات.

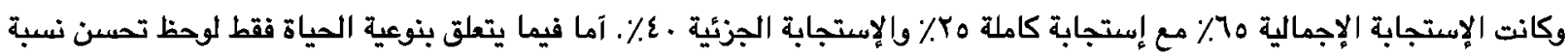

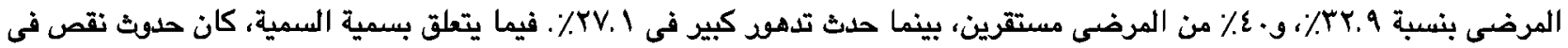

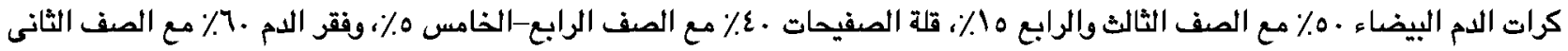

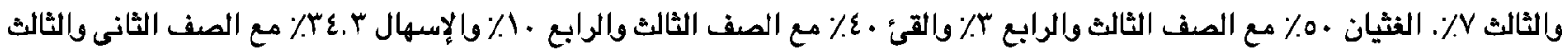

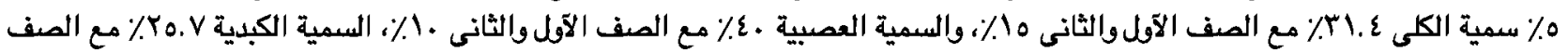

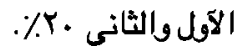

